DOI https://doi.org/10.30525/978-9934-26-146-6-37

\title{
АКАДЕМІЧНА КУЛЬТУРА СУЧАСНОГО УКРАЇНСЬКОГО ЗАКЛАДУ ВИЩОЇ ОСВІТИ
}

\author{
Блудова Ю. О. \\ кандидат педагогічних наук, доцент, \\ доцент кафедри педагогіки, психології, початкової освіти \\ та освітнього менеджменту
}

Комунальний заклад «Харківська гуманітарно-педагогічна академія»

Харківської обласної ради

Ільїна О. 0.

кандидат педагогічних наук,

викладач кафедри педагогіки, психології, початкової освіти

та освітнього менеджменту

Комунальний заклад «Харківська гуманітарно-педагогічна академія»

Харківської обласної ради

м. Харків, Україна

В ході освітнього процесу у студентів формуються не лише необхідні професійні навички та вміння, а й особливі особистісні якості, індивідуальний стиль роботи, система ціннісних орієнтацій і стосунків до об'єктів пізнання і його результатами. Якщо перелічені індивідуальні параметри застосувати до освітньої діяльності в середній школі, то використовують поняття «культура навчальної праці», а по відношенню до вищої школи - «академічна культура». Така доцільність мотивована особливостями освітньої діяльності у ЗВО, яка включає професійну орієнтованість, наявність не лише навчально-пізнавального, а й науководослідного елемента, специфіку організації та управління освітнім процесом, а також особистісні особливості студентів як суб'єктів навчальної діяльності.

Процес отримання освіти і заняття науковою діяльністю в ЗВО організовуються в специфічному середовищі, яке базується на певних цінностях академічної культури.

В умовах процесу уніфікації освіти, активізації різних форм інтелектуальної комунікації та академічної мобільності, а також міжнародного характеру науки, випливає необхідність виділення феномена академічної культури як загального явища, що формується в процесі здобуття освіти і заняття науковою діяльністю і організації в науково-освітній сфері [4]. 
У сферу академічної культури можуть бути включені:

- Академічна діяльність - освітня і наукова

- Всі види і типи освітнього процесу від читання лекцій до індивідуальної роботи зі студентами. Наукове керівництво (студентами та аспірантами), методична робота.

- Наукова діяльність: теоретичні дослідження, архівні пошуки, лабораторні дослідження i експерименти, опитування, польові дослідження, експедиції тощо.

- Академічні інститути (університет, наукове товариство, дослідний інститут, інститут інноваційних досліджень (advanced studies), бібліотеки та архіви, фонди, галузеві та відомчі центри, інститути i лабораторії, віртуальні науково-освітні портали, розсилки і конференції тощо) [1].

- Академічне письмо (написання публіцистичних, популярних, наукових, методичних, кваліфікаційних текстів). Це статті, есе, монографії, дипломи та дисертації, огляди, звіти, відгуки, науковий переклад, публікації текстів 3 коментарями, складання антологій i хрестоматій тощо. Сюди ж відноситься наукове редагування, рецензування, написання відгуків, створення підручників, навчальних посібників, комп'ютерних презентацій, сайтів, порталів, особистих сторінок тощо. Особливий вид науково-викладацької компетенції виявлення плагіату.

- Академічна інформатика: біо-бібліографічна компетентність, використання каталогів, баз даних, індексів наукового цитування, віртуальних джерел і бібліотек, електронного пошуку, в тому числі пошуку достовірних джерел в Інтернеті. Поінформованість про події в академічному світі - інтернет-розсилки.

- Академічна комунікація: конференційна діяльність, академічна риторика, професійна етика автора, викладача, академічне право, науково-кваліфікаційні заходи (захист дипломів, дисертацій, обговорення літератури). Ритуали, традиції, табу, дрес-код. Вчений у віртуальному світі: мережевий етикет («нетикет»), етика і практика електронної комунікації. Ідентифікація дослідника (Curriculum Vitae або резюме, список наукових праць, WWW-сторінка тощо).

- Академічна мобільність: студентська, викладацька, наукова. Невитратні види академічної мобільності [1].

- Академічний менеджмент - управління та організація академічними інститутами та проектами. Академічний фандрайзинг. Проектрайтинг.

- Підвищення кваліфікації та академічного статусу (навчання у відповідних інститутах, на курсах тощо, самостійна робота в 
міжнародних інститутах та центрах інноваційних досліджень (advanced studies), захист дисертацій, отримання вчених ступенів і звань).

Академічна культура в тій чи іншій мірі властива будь-якому 3ВО. В якості першого індикатора можна виділити успішність навчання в 3ВО, проте сьогодні пред'являються все нові вимоги до оцінки якості освіти. Гарна успішність не завжди гарантує практичну i професійну успішність. Практичне мислення відрізняється здатністю швидко схоплювати ситуацію, виділяти в ній завдання і фактори, що визначають і впливають на ситуацію, знаходити рішення. Практичне мислення за своєю соціальною значущістю не поступається теоретичному. Зараз виникла потреба будувати освітній процес не тільки в контексті академічної освіти (тобто теоретичної), але і орієнтуватися на практичне вирішення реальних завдань [3]. Такий погляд на проблему зумовив появу компетентнісного підходу до освітнього процесу.

Під професійною компетентністю розуміється інтегральна характеристика, яка визначає здатність вирішувати реальні завдання, що виникають в процесі професійної діяльності, грунтуючись на знаннях, цінностях і досвіді [3]. Вміти вчитися в контексті компетентнісного підходу означає вміння переводити інформацію в знання, тобто практичне застосування інформації в процесі організації і результатах діяльності [2].

Особливість компетентнісно-орієнтованого професійної освіти полягає в орієнтації процесу професійної підготовки на отримання конкретних результатів вирішення задач. Таким чином, під академічної культурою можна розуміти високий рівень оволодіння технологіями пошуку інформації та пї подальшого перетворення в знання. В іншому випадку процес навчання зводиться до накопичення інформації, яку неможливо застосовувати при вирішенні практичних завдань. Введення поняття «компетентність» і «компетентності» дозволяє представити модель академічної культури як комплекс освітніх компетентностей [3].

Академічна культура являє собою складне утворення. До сфер академічного середовища відносять навчальну та наукову діяльність, академічні інститути, академічну інформатику, академічне письмо i комунікації, академічну мобільність, академічний менеджмент, підвищення кваліфікації та академічного статусу [1]. На наш погляд, даний список необхідно доповнити сферою студентського самоврядування: волонтерська діяльність; кураторство; проведення культурно-розважальних, спортивних та наукових заходів; студентські об'єднання і гуртки тощо. Вища школа заохочує і стимулює у студентів бажання брати участь у громадському житті закладу освіти, факультету, 
оскільки це служить формою освітньої роботи зі студентами, розвиває у студентів необхідні компетенції.

Без глибокого впровадження в розуміння функціонування сучасної академічної культури неможлива плідна робота і успішне навчання. Ми вважаємо, що слід розглянути можливість вивчення академічної культури як окремої дисципліни на рівні магістратури усіх спеціальностей. Це дасть можливість підготувати компетентних членів академічної спільноти, які володіють способами i методами інформаційного пошуку, саморепрезентації, написання текстів, планування та реалізації проектів, кваліфікаційних робіт, роботи в міжнародному науковому співтоваристві, віртуальному інформаційному просторі тощо. При цьому методи навчання та підвищення кваліфікації повинні відповідати сучасному рівню завдань і можливостям їх реалізації.

\section{Лiтература:}

1. Академічна чесність як основа сталого розвитку університету / Міжнарод. благод. фонд «Міжнарод. фонд дослідж. освіт. політики»; за заг. ред. Т. В. Фінікова, А. С. Артюхова. Київ : Таксон, 2016. 234 с.

2. Герцюк Д. Академічні свободи у системі цінностей вищої освіти: еволюція і сучасний стан. Вісник Львівського університету : Серія педагогіка. 2009. Вип. 25. Ч. 4. С. 16-24.

3. Рашидов С.Ф. Університетська автономія та академічна свобода складова цінностей громадянського суспільства. Духовність особистості: методологія, теорія і практика. Т. 1 (42). 2011. С. 27-35.

4. Юринець Ю. Принципи академічних свобод як запорука демократичності вищої освіти: міжнародно-правовий аспект. Юридична газета. 2011. № 15 (276). С. 24. 